University of Northern Colorado

Scholarship \& Creative Works @ Digital UNC

$1-1-2008$

Raise Your Profile: Build Your Program

Jennifer Nutefall

Deborah Gaspar

Follow this and additional works at: https://digscholarship.unco.edu/libfacpub

Part of the Library and Information Science Commons 


\title{
Raise Your Profile: Build Your Program
}

\author{
Nutefall, Jennifer E. \\ Gelman Library, George Washington University \\ jennifer.nutefall@oregonstate.edu \\ Gaspar, Deborah \\ Gelman Library, George Washington University
}

This is the author's peer-reviewed final manuscript, as accepted by the publisher. The published article is copyrighted by Taylor \& Francis and can be found at: http://www.tandfonline.com/toc/wpsq20/current.

Citation: Nutefall, J. E., \& Gaspar, D. (2008). Raise your profile: Build your program [Electronic version]. Public Services Quarterly, 4(2), 127-135. doi:10.1080/15228950802202432 
Running head: RAISE YOUR PROFILE

Raise your profile: Build your program

\begin{abstract}
To raise the library's profile within the campus community, it is critical to create a strategic plan and align library goals with those of the university. At George Washington University's Gelman Library, the instruction librarians gained internal and external support to hire two new instruction librarians to better support collaboration with the new university writing program. The library then used assessment data to successfully advocate for an additional two positions.
\end{abstract}


Running head: RAISE YOUR PROFILE

Raise your profile: Build your program

Jennifer E. Nutefall and Deborah Gaspar

\begin{abstract}
To raise the library's profile within the campus community, it is critical to create a strategic plan and align library goals with those of the university. At George Washington University's Gelman Library, the instruction librarians gained internal and external support to hire two new instruction librarians to better support collaboration with the new university writing program. The library then used assessment data to successfully advocate for an additional two positions.
\end{abstract}

KEYWORDS: Administrative support, information literacy, strategic planning

INTRODUCTORY NOTE

Jennifer E. Nutefall, MLS, is Instruction Coordinator at Gelman Library, George Washington

University

Email: jnutefal@gwu.edu

Deborah Gaspar, MLS, Ed.D., is Instruction/Collection Development Librarian at Gelman Library, George Washington University

Email: dgaspar@gwu.edu

Mailing address: 2130 H Street, NW, Washington, DC 20052 
In 2002, the George Washington University released an aggressive strategic plan for academic excellence designed to enhance intellectual engagement of undergraduate and graduate students. The plan outlined a writing program that included a one-semester, research-intensive course required of all freshmen followed by two writing development courses taken in students' chosen disciplines. After the strategic plan was released, the Gelman Library revised its own strategic plan to incorporate objectives focused on the writing program by integrating information literacy into the new curriculum. Achieving these goals led ultimately to a doubling of instruction sessions and the addition of four new instruction librarians. This article will describe three important steps to realizing programmatic growth: strategic planning, building internal and external support, and using evidence provided by various assessment strategies to report to all stakeholders.

\section{Literature Review}

For information literacy to be integrated within the curriculum, it must first "be incorporated as an essential aspect of the academic structure of the institution" (Hunt and Birks 2004, p. 6). Clearly, university administrators must learn about information literacy and understand its value to the students. As early as 1995, Hannelore Rader addressed curriculum changes taking place in colleges and universities and asserted that librarians must become involved. She argued that "it is up to librarians to maximize their potential and to be in position to assume their role in the teaching and learning process as reforms take place" (Rader 1995, p. 277). How can librarians accomplish this? Three factors that facilitate integration are strategic planning, internal and external support, and assessment. 
Strategic planning is critical to organizational success and is not unique to George Washington University. A strategic plan details concrete steps explaining how the organization will move forward on key initiatives. For example, the library at National University designed programming to support distance learning and wrote "the goals and objectives listed represent the immediate priorities of the library for the next several years and form the basis for more specific action items and annual assessment" (Second, Lockerby, Roach, and Simpson 2004, p. 410). Furthermore, it is critical that the library's strategic planning documents link to specific objectives and goals of the institution. Owusu-Ansah (2004) promoted planning with clear objectives stating "clearly, like any department on campus, the library has to contemplate its programs and solutions within the overall mission and objectives of the parent institution" (p. 5).

Both external (university) and internal (library) support are critical to successful program building. Collaboration with external parties such as faculty, raises the profile of the library and creates stakeholders for library programs. Collaboration between faculty and librarians also builds relationships with individual faculty members and provides opportunities for programmatic alignment. Raspa and Ward (2000) defined collaboration as "a more pervasive, long-term relationship in which participants recognize common goals and objectives, share more tasks, and participate in extensive planning and implementations" (p. 5). As Gelman librarians learned, collaboration requires commitment coupled with shared ownership of a project.

Internal collaborations are equally crucial when one program grows. Timely communication garners continued support from other departments. "Consistent, constant communication is vital . .. Providing employees with information is only half of the obligation. The other half is to listen to their concerns, views, and feelings" (Cook 2006, p. 232). This is essential to organizational 
health as competition for funding and ranking on the administrative agenda can derail good programming.

Formative, ongoing assessment contributes to solid program design. Holliday and Fagerheim (2006) provided details on the role of formative assessment in the English department at Utah State as they worked to rewrite the curriculum to include information literacy and library instruction. Following the first year of implementation, the curriculum at Utah State was revised based on what they had learned through assessment. Of course, positive feedback should be broadcast to all stakeholders. In the case of Gelman library, assessment feedback supported the need for additional librarians to build on the success of the freshmen writing courses.

\section{Strategic Planning}

To implement the new writing and research program outlined in the strategic plan at George Washington University, a University Writing Development Program Task Force was formed and charged with the creation of the new program. The library addressed this new initiative, particularly the emphasis on undergraduate research, in its 2002-2005 strategic plan. The library document focused on the university's emphasis on undergraduate research by including an objective to integrate information literacy into the curriculum for the new writing program. To meet this objective, the plan advocated librarian participation on the University Writing Development Program Task Force.

The library's Instruction Coordinator served as a member of the task force along with select faculty. Their work resulted in the creation of the University Writing Program (UWP), which includes University Writing 20 (UW20), a four-credit, one-semester course required of all 
freshmen, and Writing in the Disciplines (WID) courses required during students' sophomores and junior years. Task force participants determined "the scholarship of both composition studies and library studies point to the same conclusion: both writing and research should be understood as epistemic and recursive" (Nutefall and Ryder 2005, p. 308). The existing team of five instruction librarians designed a curriculum for information literacy, drawing on the definition published by the American Library Association (1989), as a "set of abilities requiring individuals to recognize when information is needed and have the ability to locate, evaluate, and use effectively the needed information." The task force adopted the information literacy curriculum and recommended that each UW20 section include two library instruction session taught by a librarian working with that section. Each librarian partnered with several writing faculty members as assigned by the Instruction Coordinator and the Director of First-Year Writing. This faculty-librarian partnership would facilitate effective integration of information literacy into the curriculum. UW20 sections were capped at fifteen students to ensure engagement and optimal learning. The web site for the First Year Writing Program (2007) emphasizes this partnership:

Research component: Each section of UW20 is assignment a librarian from the Gelman Library System and assessments have shown that students profit from his or her involvement by gaining the skills and confidence as researchers that will serve them well throughout their college career. As they participate in class sessions throughout the semester, librarians help students develop core information literacy skills, improving their ability to locate, evaluate, and use information as independent, life-long learners. Collaborating with the course instructor, the librarian conducts in-class sessions on various aspects of research, such as topic formulation, search strategy, and the evaluation of sources. In addition, the librarian may meet regularly with students in one-on-one and 
small group settings, to provide guidance as students work through their research projects. (http://www.gwu.edu/ uwp/fyw/fwy-about.htm).

\section{Internal and External Support}

The task force proposed a gradual implementation of the new program. During the 2003-2004 school year, one-third of freshmen enrolled in UW20 courses, followed by a two-thirds enrollment during the 2004-2005 school year. Full implementation occurred during the fall semester of 2005 . This introductory process provided the university with time to hire quality faculty to teach writing to 2,500 freshmen annually. It was clear, however, that full implementation would stretch existing library staff.

With the increased emphasis on instruction, internal priorities had to shift to meet the anticipated demand. Librarians in the Education and Instruction Group (EIG) teach the majority of instruction sessions. Critical to the success of this new initiative was the support of the Associate University Librarian (AUL) for Public Services and the University Librarian.

Before the implementation of UW20 began in fall 2003, the Instruction Coordinator realized that the library's commitment to the freshman course would require additional instruction librarians. A formal request for additional librarians was taken to the library's administrative group in early 2003. In March 2003, the administrative group asked the Instruction Coordinator for more information, specifically for an estimate of the annual impact of implementing the writing program on instruction librarians. Members of EIG were asked to consider: how many additional classes they expected to teach; what was the maximum number of classes each instruction librarian could teach; to document how many classes were taught in addition to freshmen 
English, the precursor of the UW20 course; and to provide a timeline for hiring based on the gradual implementation of UW20.

The library administration determined that continued involvement in the UWP would benefit the library and provide an increased profile on campus. University Librarian Jack Siggins took the projections on the increase in instruction responsibilities (see Table 1) to the Executive Vice President for Academic Affairs.

The library administration continued to articulate the commitment to the University Strategic Plan and the UWP in the 2004-2005 budget. One of the top funding priorities was for two new instruction librarian positions. The AUL for Public Services provided information on the programmatic impact if the positions were not funded, including an estimate of non-UW20 instruction sessions that the library could no longer teaching without additional manpower. In February 2004, the executive vice president for academic affairs approved the new positions and provided the library with funding to hire two instruction librarians. These new library positions emphasized the instructional role but also included responsibilities in other library activities, specifically collection development. One librarian was hired for the start of the fall 2004 semester and another for start of the spring 2005 semester.

As planned, full implementation of the University Writing Program occurred in fall 2005 and all 2500 freshmen enrolled in UW20 courses. Once again, the executive vice president for academic affairs provided funding for two additional instruction librarian positions, bringing the total new librarian positions to four. As discussed below, this second set of positions was approved based on positive assessment data. The additional librarian positions have proven critical to the 
instruction program at the library as the number of instruction sessions has increased from 294 in academic year 2003-2004 to 625 in academic year 2006-2007.

\section{Evidence/Assessment}

Formative assessment reports played a key role in the successful funding requests for the new positions. Particularly important to this process was feedback from students enrolled in UW20 courses.

In January 2006, the Office of Academic Planning and Assessment issued a two-year assessment report documenting the success of the University Writing Program. The report also assessed the involvement of the library. The office wrote that "having a research librarian assigned to each section increased students' comfort with the library and improved their research skills. Over three-quarters of the students indicated that they were comfortable using the library for research" (Beil, Dam, \& Landry, 2006). The report went on the say that "in addition, seventy-three percent of the students who were taking at least one other class that required significant research found the research skills very useful in other class(es). In an analysis of an open-ended question about the most useful aspect of the research instruction, students identified the demonstration of online article databases; learning ALADN [Gelman's portal to online resource]; and the demonstration of search engines and powerful search techniques as most helpful” (Beil et al. 2006).

The Office of Academic Planning and Assessment gathered student feedback using end of semester course evaluations. Table 2 contains a summary of responses from end of semester course evaluations from 2003-2006. This information was particularly useful when requesting 
funding for the third and fourth instruction positions. The questions on the surveys varied slightly between academic years.

\section{Conclusion}

Additional staff is frequently necessary to meet the program goals of the library yet it is often challenging to garner support for change and expansion. Thoughtful preparation coupled with clear communication to all stakeholders can position libraries to capitalize on opportunities across the university. The experience at Gelman Library has demonstrated the benefits of strategic planning by aligned the goals of the library with those of the university, building internal and external support, and providing evidence of success through assessment results. 


\section{References}

American Library Association. 1989. President committee on information literacy final report.

Chicago, IL: American Library Association, Retrieved November 21, 2007, from http://www.ala.org/ala/acrl/acrlstandards/informationliteracycompetency.cfm\#f1.

Beil, C., K. Dam, and L. Landry, 2006. Assessment of the University Writing Program, year two: 2004-2005. Retrieved November 27, 2007 from the George Washington University, University Writing Program Web site: http://www.gwu.edu/ uwp/docs/UWP_Year2_Report.pdf.

Cook, L. 2006. The business of change. Feliciter, 52(6), 232. Retrieved November 28, 2007 from Library, Information Science \& Technology Abstracts.

First year writing. 2007. Retrieved march 14, 2007 from The George Washington University, University Writing Program Web site: http://www.gwu.edu/ uwp/fyw/fyw-about.htm.

George Washington University. 2005, May 9. Sustaining momentum, maximizing strength. Retrieved January 26, 2007 from http://www.gwu.edu/ academic/OfficeVicePresident/pdf/strg_GWBook.pdf.

Hunt, F. and J. Birks. 2004. Best practices in information literacy. portal: Libraries and the Academy, 4, 27-39. Retrieved November 28, 2007 from Project Muse. 
Owusu-Ansah, E. K. 2004. Information literacy and higher education: Placing the academic library in the center of a comprehensive solution. The Journal of Academic Librarianship, 30(1), 3-16. Retrieved November 28, 2007, from Academic Search Premier.

Rader, H. B. 1995. Information literacy and the undergraduate curriculum. Library Trends, 44(2), 270-278.

Raspa, D. and D. Ward. (Eds.). 2000. The Collaborative imperative: Librarians and faculty working together in the information universe. Washington, DC: American Library Association.

Ryder, P. M. and J. Nutefall. (2005). Teaching research rhetorically. Academic Exchange Quarterly, 9(3), 307-311.

Secord, A., R. Lockerby, L. Roach, and J. Simpson. 2004. Strategic planning for distance learning services. Journal of Library Administration, 41(3/4), 407-411. Retrieved November 28, 2007, from Haworth Press. 


\begin{tabular}{|l|l|}
\hline & $1 / 3$ freshmen enrolled in UW20 $=90$ classes \\
\hline $\mathbf{2 0 0 3 - 2 0 0 4}$ & $\begin{array}{l}\text { Non-UW20 library instruction session }=200 \\
\text { Total projected instruction sessions }=290(295 \text { actual })\end{array}$ \\
\hline & \\
\hline $\mathbf{2 0 0 4 - 2 0 0 5}$ & $\begin{array}{l}2 / 3 \text { freshmen enrolled in UW20 }=180 \text { classes } \\
\text { Non-UW20 library instruction session }=200 \\
\text { Total projected instruction sessions }=380(404 \text { actual })\end{array}$ \\
\hline & \\
\hline $\mathbf{2 0 0 5 - 2 0 0 6}$ & $\begin{array}{l}\text { All freshmen enrolled in UW20 }=270 \text { classes } \\
\text { Non-UW20 library instruction sessions }=200 \\
\text { Total projected instruction sessions }=470(528 \text { Actual })\end{array}$ \\
\hline
\end{tabular}

Table 1. Projected and actual instruction sessions during program implementation 


\begin{tabular}{|c|c|c|c|}
\hline $\begin{array}{l}\text { End of Semester Course Evaluation } \\
\text { Questions }\end{array}$ & $\begin{array}{c}\text { Percent } \\
\text { 2003-2004 }\end{array}$ & $\begin{array}{c}\text { Percent } \\
\text { 2004-2005 }\end{array}$ & $\begin{array}{c}\text { Percent } \\
\text { 2005-2006 }\end{array}$ \\
\hline \multicolumn{4}{|l|}{ UW20 improved my research skills } \\
\hline Strongly agree/Agree & $70 \%$ & $75 \%$ & $73 \%$ \\
\hline Neutral & $18 \%$ & $17 \%$ & $19 \%$ \\
\hline Disagree/Strongly disagree & $11 \%$ & $7 \%$ & $7 \%$ \\
\hline \multicolumn{4}{|l|}{$\begin{array}{l}\text { I feel comfortable using GW libraries } \\
\text { for research }\end{array}$} \\
\hline Strongly agree/Agree & $88 \%$ & $80 \%$ & $80 \%$ \\
\hline Neutral & $10 \%$ & $14 \%$ & $15 \%$ \\
\hline Disagree/Strongly disagree & $3 \%$ & $6 \%$ & $5 \%$ \\
\hline \multicolumn{4}{|l|}{$\begin{array}{l}\text { I know how to find subject specific } \\
\text { scholarly articles }\end{array}$} \\
\hline Strongly agree/Agree & $91 \%$ & - & - \\
\hline Neutral & $7 \%$ & - & - \\
\hline Disagree/Strongly disagree & $1 \%$ & - & - \\
\hline \multicolumn{4}{|l|}{$\begin{array}{l}\text { My ability to locate articles in the } \\
\text { database improved }\end{array}$} \\
\hline Strongly agree/Agree & - & - & $80 \%$ \\
\hline Neutral & - & - & $13 \%$ \\
\hline Disagree/Strongly disagree & - & - & $7 \%$ \\
\hline \multicolumn{4}{|l|}{$\begin{array}{l}\text { Having a librarian involved in UW20 } \\
\text { enhanced the course experience }\end{array}$} \\
\hline Strongly agree/Agree & $58 \%$ & - & - \\
\hline Neutral & $22 \%$ & - & - \\
\hline Disagree/Strongly disagree & $15 \%$ & - & - \\
\hline \multicolumn{4}{|l|}{$\begin{array}{l}\text { The class instruction session on } \\
\text { library and research skills led by the } \\
\text { class librarian was valuable }\end{array}$} \\
\hline Strongly agree/Agree & $64 \%$ & - & - \\
\hline Neutral & $22 \%$ & - & - \\
\hline Disagree/Strongly disagree & $15 \%$ & - & - \\
\hline \multicolumn{4}{|l|}{$\begin{array}{l}\text { In addition to UW20, I took one or } \\
\text { more classes this semester that } \\
\text { required significant research }\end{array}$} \\
\hline Yes & - & $51 \%$ & $39 \%$ \\
\hline No & - & $49 \%$ & $61 \%$ \\
\hline \multicolumn{4}{|l|}{$\begin{array}{l}\text { The research skills learned in UW20 } \\
\text { were useful in other classes I took } \\
\text { this semester }\end{array}$} \\
\hline Strongly agree/Agree & - & $77 \%$ & $68 \%$ \\
\hline Neutral & - & $15 \%$ & $20 \%$ \\
\hline Disagree/Strongly disagree & - & $8 \%$ & $12 \%$ \\
\hline
\end{tabular}

Table 2. Student responses to end of the semester surveys 